\title{
AZ ÉPÍTŐIPARI, BERUHÁZÁSI - PROJEKT KOCKÁZATOK VIZSGÁLATA ÉS FELTÁRT DIMENZIÓI
}

\section{THE ANALYSIS AND THE DISCOVERED DIMENSIONS OF CONSTRUCTION INVESTMENT PROJECT RISKS}

\author{
Szilágyi Tibor Pál ${ }^{1}$, Almádi Bernadett ${ }^{2}$, Tóth Tamás ${ }^{3}$ \\ ${ }^{I}$ Szent István Egyetem, Gazdaság- és Társadalomtudományi Kar, Regionális és Vi- \\ dékfejlesztési Tanszék, H-2103, Magyarország, Gödöllö, Páter Károly utca 1.; Tele- \\ fon / Fax: +36-28-522000, sztp@stanford.edu \\ ${ }^{2}$ Szent István Egyetem, Gazdaság- és Társadalomtudományi Kar, Üzleti Tudomá- \\ nyok Intézete, H-2103, Magyarország, Gödöllö, Páter Károly utca 1.; Telefon / Fax: \\ +36-28-522000, bernadett.almadi@gmail.com \\ ${ }^{3}$ Szent István Egyetem, Gazdaság- és Társadalomtudományi Kar, Regionális és Vi- \\ dékfejlesztési Tanszék, H-2103, Magyarország, Gödöllö, Páter Károly utca 1.; Tele- \\ fon / Fax: +36-28-522000, Toth.Tamas.Argi@gtk.szie.hu
}

\begin{abstract}
In our current publication we examine the project risks of construction investments, partly based on an earlier research, partly based on a currently undergoing primary research. Our goal is to further define and detail the risk factors that can be learnt, discovered and filtered during the investment projects so that we can create a model valid for the whole sector during a unified, standardizable model creation process. We continue to base our research on the relevant professional literature and on our earlier secondary research data. In our study, we show the deeper, qualitative background of our current primary research. During the qualitative phase, we conducted in-depth interviews (based on a partly structured interview draft in order to examine the professional opinions), and we hereby publish the results of this research.
\end{abstract}

Keywords: investment preferences, consumer behaviour, detected consumer-service provider risks, risk mitigation suggestions.

\section{Összefoglalás}

Jelen publikációnkban az építőipari beruházások projektkockázatait vizsgáljuk, részben egy már korábban lefolytatott és feltárt vizsgálatra épülő, részben egy éppen folyamatban lévő primer kutatás alapján. Célunk, hogy a már feltárt és megismert projektkockázatok közül tovább definiáljuk és részletezzük azokat a kockázati tényezőket, melyek a beruházási projektek során megismerhetőek, feltárhatóak és kiszürhetőek, hogy egy egységes szternderdizálható modellalkotás során az egész szektorra kiterjeszthető modellt alkothassunk. A kutatómunka során mind releváns szakirodalmi bázisra, mind saját, korábbi kutatási szekunderadatokra támaszkodunk. Tanulmányunkban az aktuális primer kutatásunk feltárt, mélyebb kvalitatív összefüggéseit mutatjuk be. A kvalitatív fázis keretében mélyinterjúkat készítettünk (féligstruktúrált interjúvázlat segítségével, a szakértői vélemények feltárása érdekében), és az így feltárt eredményeinket tesszük most közzé.

Kulcsszavak: beruházási preferenciák, fogyasztói magatartás, észlelt fogyasztói - szolgáltatói kockázatok, kockázatcsökkentési javaslatok. 


\section{A téma aktualitása, a kutatás fo- lyamata és szakirodalmi kötő- dése}

A témát abszolút aktuálisnak látjuk, hiszen a gazdasági paradigmaváltás hatására átrendeződött építőipari szereplők helyzete alapvető változásokon ment át. A megrendelői és fogyasztói szereplők prefe-renciáin részben- egészében végbemenő változások hatása a fogyasztói magatartás változását veti előre, mely hatásváltozás nem ér véget csak a fogyasztói oldal szereplöivel. A szolgáltatói oldal abban az esetben ha lépést akart tartani a megváltozott igényekkel, alkalmaszkodnia kell a piac többi szereplöivel együtt ehhez az igényváltozáshoz.

A gazdasági környezet változásával megváltoznak a beruházási szokások. Jól látszik ez a folyamat a 2013 első és 2014 év második negyedéve közötti időszakon is, hiszen az előző év azonos időszakával öszszehasonlítva a lakásárak szintén emelkedtek (mind nominális, mind a reál értelemben vett növekedés mértéke megközelítette az 1,4\%-ot). Vagyis a gazdasági szereplök az alacsony jegybanki kamatszint hatására kedvező feltételekkel jutnak hitelhez, ami tovább serkenti a beruházási hajlandóságot. A jövőbeni pozitív gazda-sági kilátások és az alacsony kamatszint együttesen inkább arra sarkalják a piaci szereplöket hogy megtakarításaikat befek-tessék, a helyett, hogy banki minimál-hozadékkal számoljanak [1]. A 2014. III. negyedévéről szóló új lakás építésre és építési engedélyre vonatkozó statisztikák is ezt erősítik meg, mind az építések, mind az engedélyek száma alapján (a 30\% körüli növekedés figyelhető meg a 2013 azonos időszakához viszonyítva) [2].

Ezek a kedvező folyamatok az adásvételek számának növekedésével is indexálhatóak. (A KSH információ szerint a prognosztizálható forgalom adott évben 10$15 \%$-os növekedést mutathat.)
A növekedés és a fellendülés regionális szinteken eltérö képet mutat, a legstabilabb ingatlan alpiac a Nyugat-Dunántúl-i, ahol láthatóan tartós árnövekedés figyelhető meg az FHB Index elemzése alapján [2].

A kutatásunk jelenlegi fázisát megelözően már lefolytattunk egy empirikus vizsgálatot melynek adataira épül jelenlegi vizsgálatunk. A feladat nehéz, hiszen ezek a változások folyamatosak, és szinte alig észrevehetőek. Ezért a kutatás jelenlegi primer fázisában a kvalitatív technikák kerülnek előtérbe, ahol a mélyebb összefüggéseket vizsgáljuk egy későbbi kvantitatív fázis megalapozása céljából.

Jelen publikációnkban ezért csak néhány részeredményét mutatunk be.

A hazai és a külföldi szakirodalom közül a folyamatmenedzsmenttel foglalko-zó elméleti kitekintésekre és a projektmenedzsment szakirodalmi hátterére fókuszáluk [4], mivel ez a két terület segíthet hozzá leginkább a beruházási projektmenedzsment lépéseinek vizsgálatához, kapcsolatrendszerének feltárásához. Az elmúlt évtizedek során egyre inkább felerősödnek a minőségirányítási rendszerek tudományos alapú vizsgálatainak jelentősége [4]. Jelen tanulmányunk sok területről meríti irodalmi hátterét, hiszen a projektek összetettségük következtében a diszciplínák világában internális természettel bír. Így támaszkodik a Görög M., Pupos T, Tóth T [3] tanulmányra is.

\section{Módszertani háttér}

A primer kutatásunk során a beruházási szokásokat, hajlandóságot vesszük górcső alá. Elemezzük a tervezési a beruházás előkészítési, a beruházás menedzsmentje közötti kapcsolatot, azok viszonyát és egymásrahatását, valamint az ezeket befolyásoló további, jelenleg még feltáratlan egyéb tényezőket. A primer kutatásunk kvalitatív és kvantitatív kutatási fázisból épül fel. A kvalitatív vizsgálatunk a több- 
lépcsős folyamat egyik kezdeti fázisa, mely a már korábban lefolytatott saját kutatási eredményekre (alapozó kvalitatív kutatásra) épül. Ez a módszer az építőipari- beruházási projektmunka vizsgálható fázisainak áttekintését jelenti [3], egyfajta menedzserszemlélet kibontakozását keresve.

\section{Eredmények}

A kutatás során feltártuk a beruházási hajlandóság, az építészirodák és a beruházás-előkészítés között megmutatkozó kapcsolatrendszer struktúráját, illetve annak sajátosságait. Részletesen kerestük a fogyasztói kockázatvállalási hajlandóság és a szolgáltatói kockázatcsökkentési módszerek közötti összefüggéseket. Azt vizsgáltuk, hogy milyen módon hat egyik a másik müködésére, mivel lehet motiválni a beruházókat, és milyen módon hat a megbízói bizonytalanság a tervezés és kivitelezés folyamatára, milyen financiális és emocionális okai vannak a beruházás megvalósulásának, vagy éppen annak meghiúsulásának.

\subsection{A megelőző kutatás kvalitatív eredményei}

A megelöző alapozó kvalitatív kutatásunk validálásához a kvantitatív kutatási fázist során nem reprezentatív, önkényes mintavételt alkalmaztunk, melyet elötesztelt sztenderdizált kérdőív segítségével folytattuk le. Az adatfelvétel 2011 augusztusa és 2012 áprilisa közötti időszakban zajlott $(\mathrm{N}=306)$, a kapott eredmények segítettek az újabb kvalitatív fázis tárgyköri kérédéseit tovább struktúrálni.

A megelőző, alapozó kvalitatív kutatás vizsgálati eredményei a következő kockázati dimenziókat mutatta [5]. A feltárt legfontosabb konklúziók egyike, hogy az interjúk során sikerült körvonalazni a szol-gáltatást igénybevevők (megbízók, épít-tetők, beruházók) oldaláról érzékelt koc-kázati tényezőket. Melyek a következők:

- pénzügyi-;
- idö-;

- személyi-;

- társadalmi-;

- és pszichológiai kockázatok.

A pénzügyi kockázat röviden azt jeleni, hogy elég likvid forrás, fedezet áll-e rendelkezésre ahhoz, hogy elkészüljön az építkezést. Az időkockázat a határidőre való elkészülést takarja. A személyi kockázat a nem megfelelő szakemberválasztást jelenti, amely a projekt befulladását is jelentheti. A rossz tervezö, a gyakorlattal, referenciával nem rendelkező kivitelező, a rosszul kiválasztott müszaki ellenőr stb. mind kockázati tényező. A társadalmi kockázat kicsit absztraktabb nézőpont, az egyén szerepét és a társadalom viszonyát vizsgálja. Véleményünk szerint a társadalmilag disszonáns beruházási projektek kockázata gazdaságiés politikai kockázatokat is rejt magában. A pszichológiai kockázat azt jelenti, hogy mennyire érzi majd sajátjának az elkészült beruházást az építtető.

\subsection{A jelenlegi kutatás kvalitatív eredményei}

A jelenlegi kutatási fázisban a kvalitatív interjúk lefolytatása és azok párhuzamos kiértékelése zajlik. Szeretnénk megismerni, hogy melyek a kivitelező (szállító) és melyek a megrendelő (ügyfél) által észlelt elvárások és észlelt kockázatok. Továbbá szeretnénk feltárni a projekt specifikus és az általános (projekt független) kockázatkezelési megoldásokat a stakeholderekkel. A módszer szakértői interjú. Az alanyok rekrutálása: projekttel foglalkozó, azt irányító vagy koordináló szakemberek, projektvezetők, projekt menedzserek, vagy koordinátorok. Fontos további kiválasztási szempont, hogy az alanyok különböző ágazatban tevékenykedjenek, hogy a vizsgálati szempontok ezek alapján ütköztethetők, összevethetők legyenek. A féligstruktúrált interjúvázlat tárgyköri kérdései a következő nagy 
kérdéscso-portokat járta körbe, melyekböl az összefüggések vizsgálata zajlik:

- a projekt föbb elemeinek, ismérveinek feltárása;

- a projekt előkészítése (pl.: idő, költségek, minőség, felelőségvállalás, tájékoztatás, beszámolási kötelezettség);

- és a projekt megvalósítása (pl.: kulcs elemek, teljeítésigazolás, észlelt időkockázatok);

- a projekt értékelése (pl.: megvalósulás a tervezetthez képest).

Ezen lefolytatott és jelenleg már kiértékelt kvalitativ vizsgálat féligstruktúrált mélyinterjúk keretében a következő eredményeket mutatta:

- az egyes projektek résztvevői között megjelenik az együttmüködés kockázat, ami az építöipari produktumok esetében eltérően változhat;

- jól látszik kirajzolódni az egészségügyi kockázat, ami szintén eddig nem ismert és nem vizsgált új beruházási tényezőként jelenik meg;

- valamint az információkockázat, amely okainak feltárása a további kutatómunka feladatai lesz.

\section{4. Összefoglalás}

Összességében elmondhatjuk, hogy a kutatás időszerü, mert a gazdasági hatások átrendeződésével újabb lehetőségek nyílnak meg az építészeti és beruházási szektor szereplői előtt. A tényezőket feltárva jelenleg nyolc csoportra bontottuk a kockázati dimenziókat. Jelen publikációnk része egy összetett több lépcsős kutatási folyamatnak, ami jelenleg a primer kutatási fázis kvalitatív részét jelenti. Célunk a kvalitatív ered- ményeink kvantifizálása a jövőben. Jelen kutatási fázisunkban kezdenek kirajzolódni és deffiniálhatóvá válni azok a további építőipari beruházási projektfolyamatok, amik meghatározzák az észlelt illetve rejtett projektkockázatok dimenzióit.

Ezek közül a faktorok közül sikerült újabb három nagy csoportot feltárni, melyet jelen publikációnkban ismertettünk. Ezek a tényezők a beruházási folyamatban résztvevő szolgáltatói, és szolgáltatást igénybevevői oldalát egyformán érintik. Jelenlegi eredményeink alapján kutatásunk-at tovább folytatjuk.

\section{Szakirodalmi hivatkozások}

[1] A. Csiszárik-Kocsir, M. Fodor, A. Medve: The Hungarian youngsters attitude towards the financial decisions based on a questionnaire research, The Macrotheme Review: A Multidisciplinary Journal Of Global Macro Trends 2:(5) 47-57, 2013.

[2] FHB Lakásindex: http://goo.gl/oNR1du (Letöltés ideje: 2015.02.06.11:11)

[3] Görög M., Pupos T, Tóth T.: A tervek kidolgozásának általános elvei és metodikai kérdései In: Tóth T, Cser J (szerk.) Területi és projekttervezési ismeretek. 188 p., Debreceni Egyetem Agrártudományi Centrum, Debrecen, 2007, (ISBN:978-963-9732-77-3)

[4] Kozma T., Gyenge B.: Minőségirányítási rendszerek a gazdaságban - képesitö kritérium vagy müködést támogató eszköz, CONTROLLER INFO II., Budapest, 2014, (4), 14-19.

[5] Szilágyi, T. P., Medve, A., Tóth, T.: Beruházási folyamatvizsgálat a megrendelöi döntéshozataltól a megvalósulásig In: Nagy, I. Z. (szerk.) Vállalkozásfejlesztés a XXI. században III.: tanulmánykötet. 260 p., Óbudai Egyetem, Budapest, 2013.,53-72. (ISBN:978615-5018-61-9) 